\title{
Språket ved flo og fjære
}

\author{
Språket springer ut av kroppen - derfor er det høyst betimelig at det er legene som lodder \\ dypest når det gjelder språkets utvikling. De ærede doktorander som presenteres her, \\ kunne kanskje gått enda grundigere til verks - siden tidevannet styres av månen...
}

I oktober 1967 skjedde det noe epokegjørende i norsk universitetsliv. Foran 600 tilhørere i Sophus Lies auditorium på Blindern forsvarte de to medisinerne Bernhard Getz (1923-69) og Carl Birger van der Hagen (f. 1933) en felles avhandling for den humoristiske doktorgrad. Det skjedde i regi av Det Norske Studentersamfund. Etter bestått disputas fikk de hvert sitt diplom undertegnet av rektor ved Universitetet i Oslo (1964-69) Hans Vogt (1903-86). De to doktorandene påviste at språkutviklingen hos mennesket ble påvirket av tidevannet, og at det var klare forskjeller mellom flo og fjære mål. Hvis man går helt tilbake til urtiden, kunne dette bety at da mennesket begynte å tale, sa det «bo bo». Men når havet steg, ble det til «blo blo». Som genetiker viste van der Hagen i avhandlingen til at menneskets språkutvikling også var arvelig, men med en begrensning formulert i arveloven $\S 67$, hvor det heter: «Ingen ansees at have taget Arv, med mindre han er født levende.»

Bedømmelseskomiteen var utpreget tverrfaglig. Den besto av teatersjef Mentz Schulerud (1915-2003), universitetslektor i dansk Erling Nielsen (1920-2000), journalist Nils Werenskiold (1920-91) og endelig professor i ernæringsvitenskap og senere rektor ved Universitetet i Oslo (1999-2001) Kaare R. Norum (f. 1932). Det foregikk en meget frisk disputas, og de to doktorandene forsvarte seg godt. Imidlertid ble situasjonen nokså prekær da filosofen Peter Wessel Zappfe (1899-1990) reiste seg og opponerte ex auditorio. Han påpekte at de ikke hadde tatt hensyn til det rundes problem, og denne alvorlige beskyldningen ble etterfulgt av en lærd filosofisk utredning som ingen forsto noe av. Fortsatt vet ingen hva det rundes problem går ut på.

Om de to doktorandene er det å fortelle at de var fremtredende universitetslærere. Alle medisinstudenter kjente dem. Bernhard Getz var prosektor i anatomi med forskningsbakgrunn fra skjelettets antropologi, Carl Birger van der Hagen er genetiker og arbeidet som førsteamanuensis ved Institutt for medisinsk genetikk ved Universitetet i Oslo. Han var bl.a. med på å bygge opp den prenatale diagnostikken i Norge (1).
Både Getz og van der Hagen var aktive i studentsosiale aktiviteter, bl.a. i regi av Medisinerforeningen og Medicinernes Skiklub Svartor. Getz hadde en alvorlig nevrologisk lidelse og underviste fra rullestolen, men det hindret ikke hans mange aktiviteter. Han skrev artikler og bøker og holdt foredrag og taler med medisinhistorisk innhold, gjerne med en humoristisk undertone. Høsten 1959, som var første året jeg studerte, åpnet han den makroskopiske anatomiundervisningen i følgende ordelag: «Jeg skal nu starte undervisningen om oppbyggingen av det menneskelige legeme. Det første som springer en i øynene er næsen.» Resten av timen ble brukt til en systematisk gjennomgang av dette fremtredende organ. Til slutt sa han: «l neste time skal vi dykke dypere inn i kroppen og der venter nye vyer på Dem.» Vi var helt med!

Deler av Getz \& van der Hagens avhandling ble siden trykt i Terapeutiske Fremskritt, et medisinsk informasjonsblad som utkom i årene 1955-72. Utgiver var Apothekernes Laboratorium AS i Oslo, også kalt AL. Øivind Larsen (f. 1938), senere professor i medisinsk historie, var redaktør. Larsen hadde stor sans for slike artikler, og bladet var på den tiden et forum for høyst originale innlegg. Noen av dem er med i denne serien. Vi gjengir originalutgaven av artikkelen Sprogutvikling, tidevann og arvelighet med Carl Birger van der Hagens velvillige tillatelse.

\section{Ole Didrik Lærum}

ole.laerum@gades.uib.no

Ole Didrik Lærum (f. 1940) er professor ladj.) ved Københavns Universitet og professor emeritus i patologi ved Gades institutt, Universitetet i Bergen.

\section{Litteratur}

1. Tveito K. Kromosomer er fantastiske. Tidsskr Nor Lægeforen 2006; 126 $1226-7$
Artikkelen er rikt illustrert. Figur 1 og figur 2 er hentet fra boken Physiognomiske Studier av den danske maler og offiser Sophus Schack (1811-64) (1). Han ønsket å vise likheten mellom mennesker og dyrs egenskaper - de valgte eksemplene er torsk og ravn. Figur 3 og figur 4 er fra Olav Trygvasons saga (2). Halfdan Egedius (1877-99) laget ti tegninger til denne. Mesterverket er Seidmennene på Skratteskjoer (fig 3). Figur 4 har tittelen Høvdingene ser fra holmen skipene til Olav seile forbi. Figur 6 og figur 8 er hentet fra Den nye Naturloegemetode av den tyske naturlegen Friedrich Eduard Bilz (1842-1922). Dette trebindsverket var svært populært og ble oversatt til en rekke språk. Illustrasjonene viser et bølgebadekar og «Øjenbad» (3).

\section{Litteratur}

1. Schack S. Physiognomiske Studier. 2. del. Kjøbenhavn: Nyt Dansk Forlags konsortium, 1880: 98, 80

2. Olav Trygvasons saga. I: Sturlason S. Kongesagaer. Oversatt av Gustav Storm. Kristiania: Stenersen, 1899: 159, 180

3. Bilz FE. Den nye Naturlægemetode: Lære- og Haandbog i den naturlige Lægemetode og Sundhedspleje. Bd. 1. København: Bilz Bogforlags-CentralBureau for Danmark ved Forlaget Norden, 1906: 92, 284. 


\section{Sprogutvikling, tidevann og arvelighet}

Av Bernh. Getz og C.B. van der Hagen Getz B, van der Hagen CB. Sprogutvikling, tidevann og arvelighet. Terapeutiske Fremskritt 1968; 14: 165-70, 225-30.

\section{DEL I (illustrert)}

\section{Innledning}

Om sprogenes herkomst vites intet med sikkerhet. De finnes simpelthen der hvor de forekommer. At de har gjennomgått en utvikling må anses som et faktum; det er derimot delte meninger om hvorvidt denne burde ha foregått eller hvor den burde ha stoppet.

Synet på sprogenes utvikling varierer. Noen betrakter den som

1. et filologisk spørsmål, andre som

2. et politisk spørsmål (ife brødrene Bergersen, H. Sivertsen m.fl.), atter andre som

3. et resultat av dulgte kjertlers virksomhet (med hell hevdet i en større hovedstadsavis), og endelig ser noen den som en følge av

4. Norsk Språknemnd (heretter kalt NS).

I nærværerende avhandling vil forfatterne fremlegge indisier på at utviklingen av sprogene skyldes helt andre forhold, nemlig en kombinert innflytelse av tidevannet (flo og fjærer) samt av genetiske faktorer. Vi har studert sprogets forandringer fra vannkanten og opp i fjellet, likesom vi har kunnet vise at dets arvelighet beror på en overføring av gener.

Forfatterne vil rekke en varm takk til sine instituttsjefer, som ved sin passivitet har gjort arbeidet mulig, likeså til den stimulerende innflytelse fra institusjoner som NS, Kjell Bondevik, Vogt-komiteen og Trygve Bull.

Videre vil vi takke ordbokredaktør Hellevik. som velvilligst har unnlatt å gjennomlese manuskriptet.

\section{Historikk}

Tidligere forskere har arbeidet meget med å finne tilbake til den felles sproglige grunnstamme, men deres forsøk har bare i begrenset grad ført til entydige resultater. Som et eksempel på slike lite hensiktsmessige forskningsmetoder kan nevnes den amerikaner som nå er på Ararat og der leter etter den siste rest av det opprinnelige sprog. Vi vil senere komme tilbake til hans hypoteser.

Som alle burde vite har virkelig sprogene en felles grunnstamme, symbolisert $i$ Skriften ved det såkalte Babels tårn (fra dette har man senere avledet ordet «babl» eller «babbel», det felles grunnlag for alt folkemål). Enhver videre søken i denne retning synes derfor umiddelbart lite formålstjenlig, men få. sprogforskere innser dette. Etter vår mening ligger problemets tyngdepunkt nærmere de evidente endringer i sproget: hvorfor og hvorledes. Svaret ligger dog på et ganske annet plan enn den ortodokse og paradokse sprog- forskning beveges, og det ligger klart $i$ dagen at ganske andre parametre bør være gjenstand for utforskning.

Få er oppmerksom på de tidlige observasjoner av sprogets avhengighet av flo og fjcere (heretter kalt SAAFOF). Ytre omstendigheter synes å ha hindret de praktiske utnyttelser av funnene, idet Den Norske Dictionarium eller Glosebog, hvori de ble publisert, utkom i 1646, to år før Tredveårskrigens avslutning (sml. her Gustaf Adolfs utåImodige utbrudd allerede 14 år tidligere: «Skal det dog aldrig blive Slut paa denne trædive Aars Krig?»). Det gis i bemeldte dictionarium klare henvisninger til «Fløemaal» (kommen paa Landet) som kontrast til «Fiære-maal» (i.e. Skickeligt, Jeffnt sive liigt), og hvor uttrykket «Dæ kand væra so fiære, i.e. Det kand høffue i Haab sive vel skicke sig» klart adskilles fra alle med «Fløe-maal» sammenhengende uttrykk. Dette er klart relevant til vår oppfatning om at sprogene under fjære fjerner seg mindre fra hverandre enn under flo.

Når det gjelder tidlige observasjoner som har relevans til vårt annet parameter, nemlig det genetiske, faller det her naturlig å nevne Christian den Fjerdes Norske Lov, som anerkjente retten til å beholde nedarvede spesielle målformer. I Anden Bog XI om Vect oc Maal gis dispensasjon fra påbudet om å nytte det offisielle «Tynde Maal» til

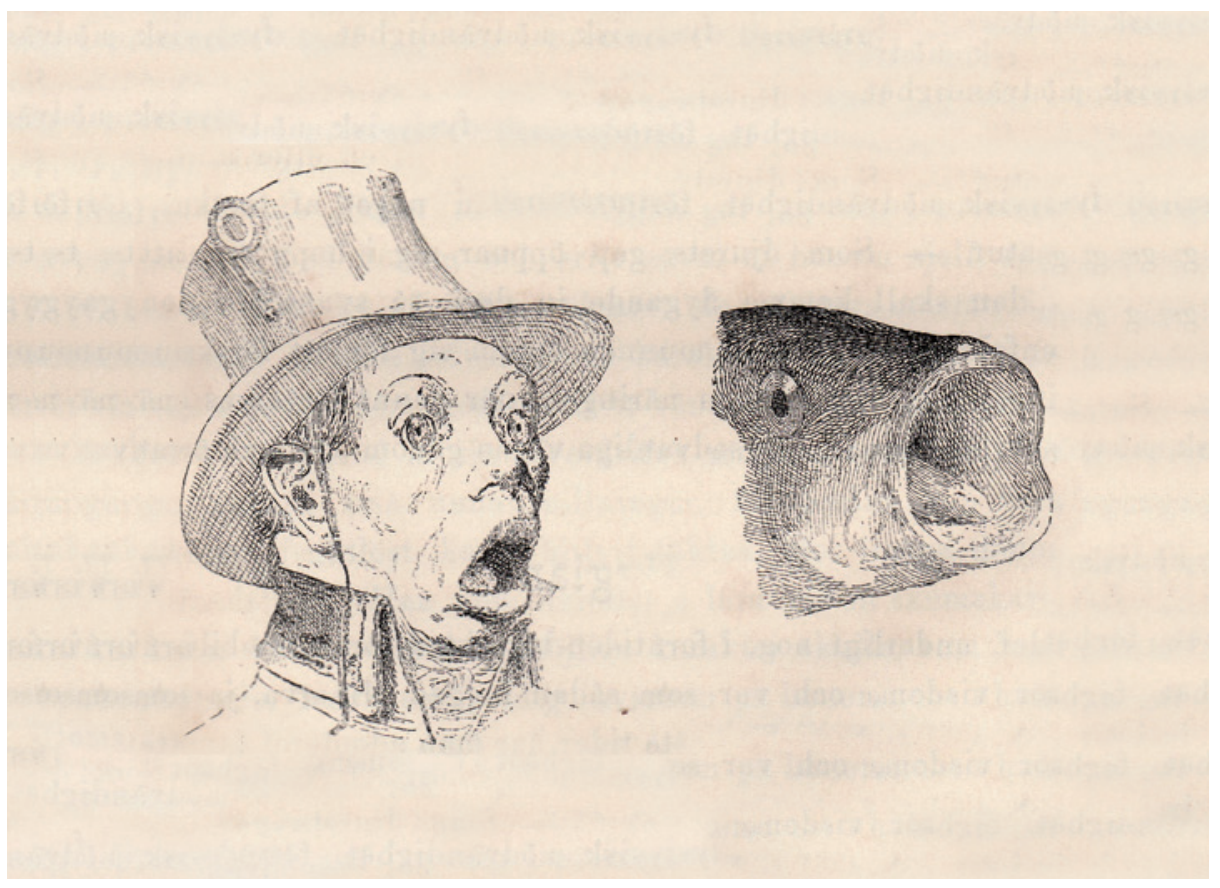

Fig. 1. Fysiognomi under påvirkning av flo mål. Marin type.

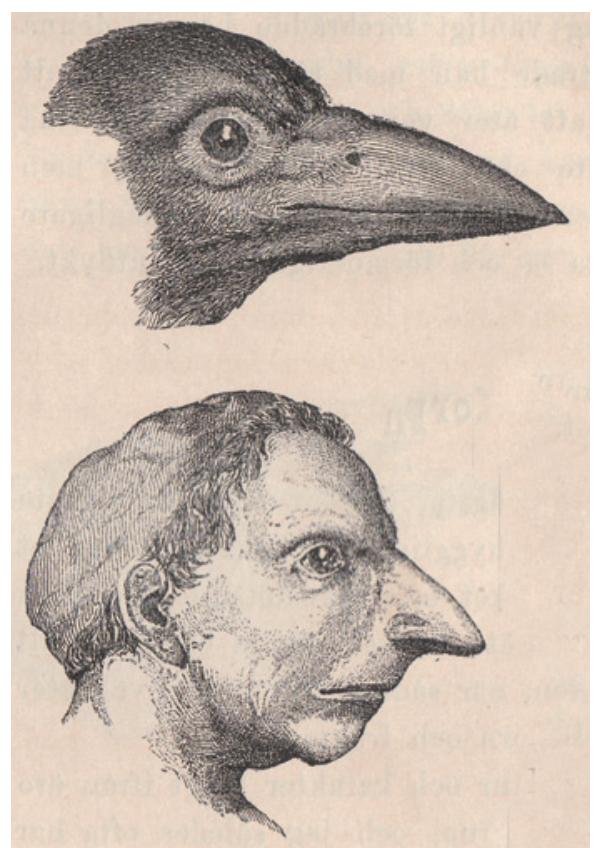

Fig. 2. Fysiognomi under påvirking av fjære mål. Alpin type. 


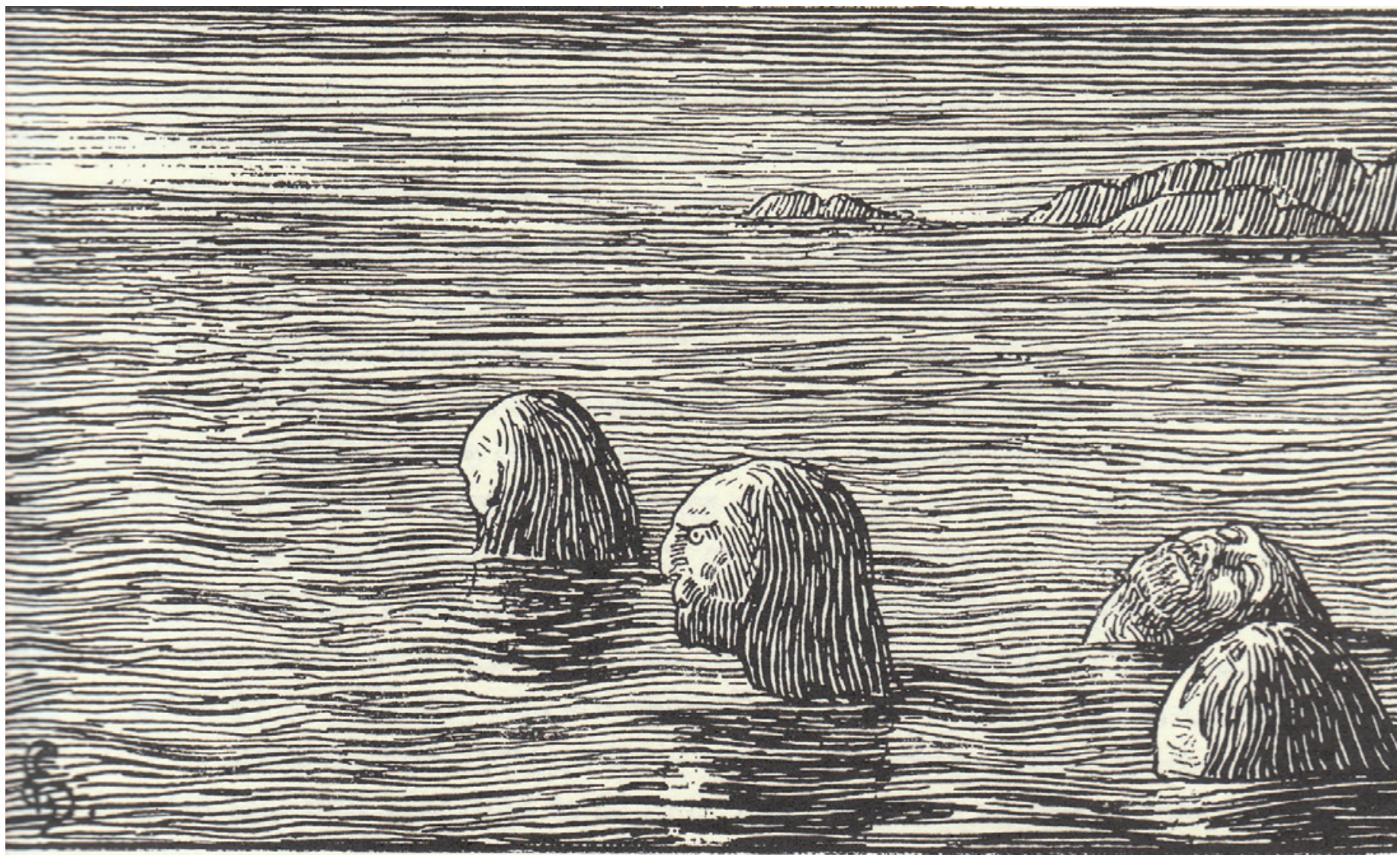

Fig. 3. Betraktning av tidevannet. (Forfatterne til venstre.)

innbyggerne $\mathrm{i}$ «Riberhus Len som aff arildstid altid haffuer hafft sit Særmaal».

Unntagelser fra generelle regler for mål ble også gjort gjeldende for andre populasjonsgrupperinger enn rent geografiske, idet «Efter Rescript af 9de Jul. 1745 skal ale virkelig enroullerede Skieløbere, naar de sig første Gang med Leyermaal forsee, for aabenbare Skrifte og Bøders Betaling, ligesaavel som Landeværn-Mændene være befriede». (Såvidt vi har brakt i erfaring fra Medicinernes Skiklub, Svartor, står dette reskript fremdeles ved makt.)

Til slutt i denne historiske oversikt vil vi gjerne av nasjonale grunner fremheve at Norges Arvelov ble fremlagt flere år før Mendels epokegjørende arvelov der som kjent gjelder for erteplanter.

Det synes etter det anførte klart at den sproglige utvikling influeres av tidevannets faser likesåvel som at arvelige faktorer er av stor betydning.

\section{Metodikk}

Å få en teknisk adekvat metodikk bød på store problemer. Dog har det vært mulig å utarbeide subtile metoder som har vist seg fruktbare. Sett på bakgrunn av den ringe støtte som nok må påregnes ved parallelle undersøkelser, kan det fremheves at apparaturen er rimelig og at tidevannets store energireserver lar seg utnytte som kraftkilde. Sensibiliteten ved selve scoringsteknikken er høy. Man har benyttet seg av: A. Litterære undersøkelser.

B. Fysiognomiske studier. (Se fig. 1 og 2.)

C. Direkte studier av tidevannet. (Se fig. 3 og 4.)

D. Auditive registreringer av sprogvariasjoner.

E. Kryssningsforsøk utført i Slottsparken.
Forfatterne har derfor satt seg fore:

1. Å kartlegge tidevannsinnflytelsen.

2. Å analysere de genetiske faktorer.

3. Å vise hvorledes tidevannets evige vekslen, via genetiske mekanismer, såvel har bevirket som fremdeles bestemmer den sproglige utvikling.

«Bry Dem ikke om pensum; jeg har protestsanger som hovedfag, og kubanske sanger som bifag»

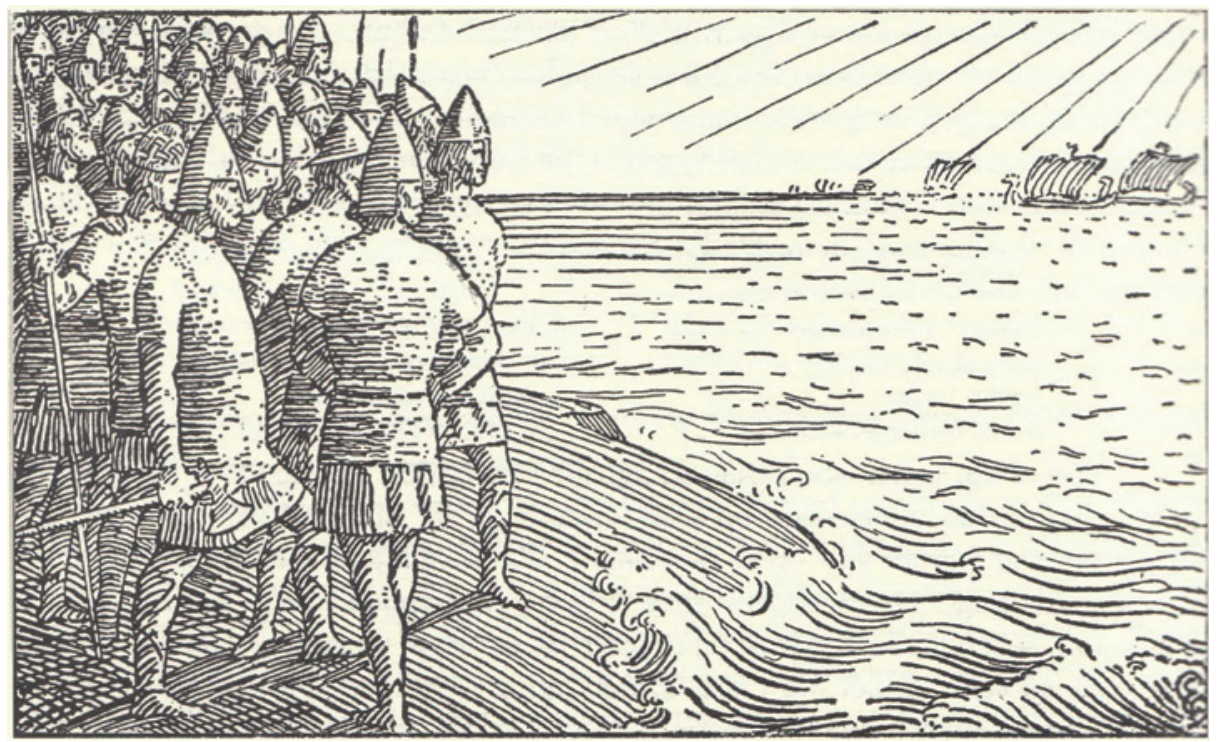

Fig. 4. Tidevannets virkning på humant materiale. (Forfatterne til høyre.) 


\section{Sprogutvikling, tidevann og arve1ighet - Del II}

\section{Egne funn}

Kartlegging av tidevannsinnflytelsen.

Det er et brennende spørsmål i vår tid å finne seg selv. (Enkelte ganger skal det også være vanskelig å finne andre. Sitat kriminalsjefen). Man treffer alvorlig tenkende mennesker som reiser fra sted til sted bare for å oppdage at der er de heller ikke. Det synes under disse forhold ikke underlig at man som et ledd i denne uavlatelige søken også leter etter sprogets opprinnelse og dets utvikling. Når vi nå begir oss ut på denne upløyete mark og retter spørsmålet: Hvem vet?, kan vi med rette svare: Få

I den innledningsvis nevnte Norske Dictionarium fra 1646 finner vi bekreftelse på at man allerede den gang - riktignok ubevisst $\neg$ må ha vært klar over forskjellen på flo og fjære mål. Således finner vi at en reise til vanns benevnes «faer» (eks.: «Kand eg faa faer med dock»), mens en ferd til fjells heter «fær» (eks.: «Første færa»). Vi ser altså straks hvorledes a-en forsvinner i og med at reisen flyttes opp på land, samtidig som vi aner den felles grunnstamme.

Vanskeligere blir det å forklare hvorfor en båt etter dette kalles en «færing»; her står vi overfor en av de inkonsekvenser som vi også finner hos H. Ibsen, som i Peer Gynt lar fjære mål (handlingen foregår høyt til lands) være splittet, som i rimet:

«Se til gaards, hvert andet rude hul er fylt med garnle klude.»

Forklaringen finner vi muligens i samme dictionarium, hvor det heter: «Flo sive Flo Siø siges at skie i Norge naar Maanen staar i Sudvest oc Nordvest, mens Verden staar ligesom Fiære skier: Naar Maanen staar i Sudoest oc Nordvest.» Sammenhengen med beliggenheten av både Fær-øene og Suderøene nær vannkanten kan bidra til å forklare sammenhengen.

Likeledes er det interessant at man allerede på 1600-tallet sammenstillet «Fløe-maal» med sjø-mal («Naar Søen i Floden er kommen paa Landet»), hvilket forfatterne tør ta som en ytterligere bekreftelse på den tidlige påvisning - om enn ikke erkjennelse - av forskjellen mellom flo og fjære sprog. At fjære sprog befinner seg på det jevne, lite differensierte stadium, bekreftes av betydningen av selve ordet «Fiæra»: «Jeffn sive liige», mens «Flaae» defineres som «Hastigt uforvarende Uvejr».

Vi har også et utmerket eksempel på forskjellen mellorn flo og fjære i det gamle «rie om» (falle omkull), som straks vi kommer ut på sjøen, heter «rey om» (eks.: «Baaden rey om paa Siono»). Enheten i fjære-mål kommer videre frem når man vet at «ri» kan

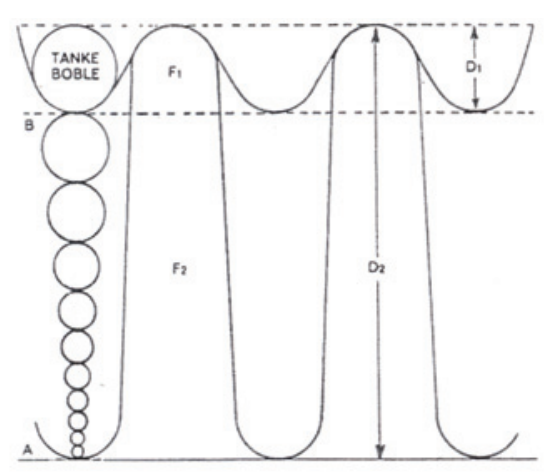

Fig. 5.

bety bjerk (vi ma her formode at det dreier seg om en fjellbjerk), og at det likeså kan bety smerte (bjerkeris). Således er fjæremålet enhetlig og knyttet til landjorden.

En ytterligere illustrasjon av de nevnte forhold har vi i det avbildete diagram etter Maharishi (fig. 5), som viser hvorledes en bølge under flo blir mer uensartet jo mer den opptar i seg de dypere lag av havet. Man vil derav utvungent forstå at fjære sprog er mindre preget av forskjeller enn språget under flo. Vi ser av diagrammet hvorledes tankebobler som under flo tid på dypet ligger langt fra hverandre etter hvert som de når høyere opp, kommer til å flyte nærmere sammen mot en enhet. Linjen B markerer det kritiske sprogpunkt, F1 fjære og F2 flo. Jo mer sistnevnte gjør seg gjeldende, desto mer vil sproget D2 anta varierende form på bekostning av det enhetlige sprog D1.

\section{En analyse av de genetiske faktorer.}

$a$. Arvelighetens lovmessighet.

Når det gjelder arvelige faktorers innflytelse på sprogutviklingen har det lenge vært uenighet om disses betydning i forhold til rniljøets, likesom det er omdiskutert hvorvidt slik arv er ventet eller uventet. Arvelovene skjelner her skarpt mellom begrepene. Det kan således ifølge Mendel være ventet at man arver sin fars nese, mens Lütkens utgave av den norske arvelov fremhever det uventede $i$ at man arver sin mormor hvis hun døde som barn.

\section{Arvelovens $\S 67$ heter det at «Ingen} ansees at have taget Arv, medmindre han er født levende». (Man merker seg at dette bare gjelder hankjønn.) Dog er loven mer generelt formet i sin $\S 68$, som sier følgende: «Er Barn undfanget, men ikke født, naar Arven falder, bliver denne at forbeholde Barnet, indtil det har viist sig, om det fødes levende. Kan dette ikke bevises, bliver Arven at tillegge dem, der paa den Tid, Arveladeren døde, vare hans Arvinger.» Hvis man således dør før man er født, kan man arve uventet.
Sproget i Arveloven bærer preg av å være blitt til i fjære tid. Ganske annerledes er det - hvilket også må ansees som forventet $\neg$ med Sjøretten, som i Platous utgave bærer tydelig preg av flo. Her finner man sproglige varianter som Skabets Peder i stedet for Skibets Reder, Søørretten for Søretten, ligesaalet for ligesaalidt, merkelig for naturlig etc. Bemerk her at det overhodet ikke er tale om fjellørret.

\section{$b$. Krysningsforsøk.}

I erkjennelse av at tilstrekkelig omfattende krysningsforsøk i humant materiale for a påvise genetisk determinering av familiær eller gruppevis opptreden av enkeltfenomener, ikke lar seg gjennomføre, har vi innsett nødvendigheten av enklere testsystemer. I betraktning av den dominerende stilling planter har hatt som forsøksorganisme i genetikken (Mendel benyttet som kjent erteplanter), har vi funnet det naturlig å krysse sprogblomster. Blomstene «Erter ut av en sekk» (Jfr. Mendel) x (i.e. krysset med) «Perler på en snor» var vårt første forsøk med F1 (i.e. første filialgenerasjon) «Erter på en snor». Dette forsøk bekreftet for øvrig at genene er lineært ordnet. Vi har videre kunnet påvise at sprogblomster som representerer F l-generasjonen har kunnet gi opplysninger om foreldregenerasjonens (parentalgenerasjonens) genotype.

Vesentlig for våre konklusjoner er en krysning utført i Slottsparken mellom to sentenser fra H. Ibsens Peer Gynt, nærmere bestemt et marint (sive flo sjø) eksemplar, fra båthvelvet: «Der slap det ud af ham til sist. Han var en traakig moralist» ... og et alpint eksemplar (fjære sjø) fra Bukkerittet: «Broken har dog fatt en revne: men det er knapt verdt at nevne. » F1-generasjonen består av to hybrider: «Der slap det ud af ham til sist. Broken har dog fatt en revne», som er dominant over «Han var en traakig moralist, men det er knapt verdt at nevne». Man merker seg at krysning av sprogblomster med innvirken av tidevannet gir signifikante resultater.

c. Genetisk kode og alfabet. Mutasjoner som årsak til variasjon.

Den genetiske kode består av symboler som i form av bokstaver er ordnet lineært på kromosomene (som erter på en snor), og må ansees som et nøyaktig program for alle genetisk determinerte manifestasjoner. Som man skulle vente er den genetiske kode skrevet i det engelske sprog. Maynard Smith viste i 1962 hvordan gen kan bli til ord, (GENE til WORD), se tabell 1) ved trinnvise mutasjoner som følge av enkeltendringer av bokstaver, og hvor hvert mellomledd har betydning. 
GENE

GONE

GORE

WORE

WORD

Tabell 1.

Prosessen er reversibel. Denne type mutasjon benevnes punktmutasjon. Andre former for mutasjoner er:

bortfall av bokstaver - delesjon, tillegg av bokstaver - insersjon, ombytning av ett eller flere symboler, dvs. en endret rekkefølge på kromosomet inversjon.

1. Generasjonsutvikling i sproget illustreres best av de tilfeller hvor navnearv avviker fra ovenfor anførte regler. Mekanismene er særlig delesjon og insersjon: P-generasjon Jakob von der Lippe $\neg F 1$-generasjon Just Lippe (her kan man dog ikke utelukke miljøfaktorer), samt (etter Hvem er hvem) P-generasjon gardbruker Ugjesteby F1-generasjon Omar Gjesteby.

2. Den ortodokse sprogutvikling er vist $i$ tabell 3. Bemerk her overgangen fra en flo type til en fjære type, og at prosessen er reversibel! eventuelt gjennom endrede ledd.

$\begin{array}{ll}\text { BULL } & \text { VOGT } \\ \text { TULL } & \text { VOLT } \\ \text { TOLL } & \text { VOLL } \\ \text { VOLL } & \text { VILL } \\ \text { VOLT } & \text { BILL } \\ \text { VOGT } & \text { BULL }\end{array}$

Tabell 2

3. Den paradokse sprogutvikJing er meget vanlig og er vist i tabell 3. Man bør dog merke seg at meget som er teoretisk mulig ikke lar seg gjennomføre i praksis.

BULL

BULE

TULE

TUNE

TUNG

TYNG

LYNG

Tabell 3.

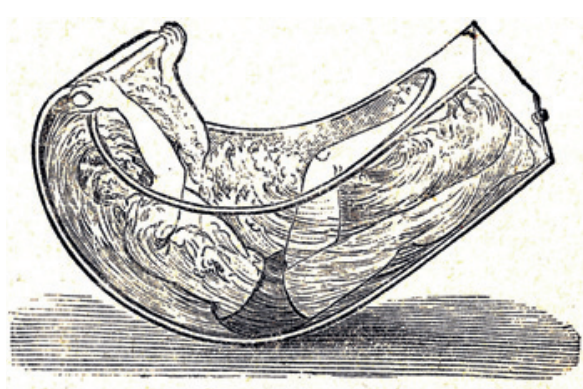

Fig. 6.

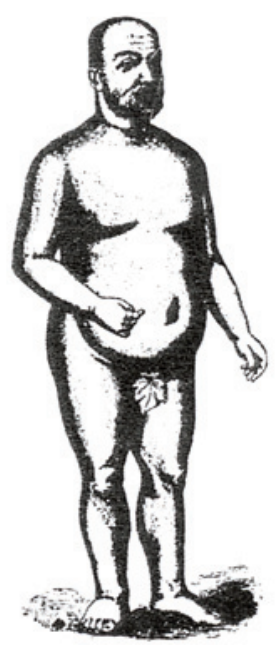

Fig. 7.

3. Tidevannets innvirkning på genene.

Eksperimenter.

a. Observasjoner.

Her vil vi bare henvise til Fig. 3 og 4 (se del I) hvor forfatterne er avbildet sammen med nordlendinger. Sammenhengen mellom den store forskjell på flo og fjære i denne landsdel og beboernes sprog er her avslørt for første gang.

$b$. De ovenfornevnte observasjoner viste at toneleie, eventuelt variasjoner i samme, er genetisk bestemt og påvirkelig av tidevannet. Dette prinsipp ble først utnyttet under vår behandling av en mannlig bass-sanger (fig. 7). Denne konsulterte oss fordi han bare kunne synge høye toner hvilket harmonerte dårlig med hans profesjon som bass-sanger.

En utvidet behandlingsmetode var påkrevet, og denne fant vi i bølgebadet (se fig. 6). Dette hadde en umiddelbar effekt. Dog var første gangs behandling bare delvis vellykket, idet hans stemme kun ble senket én oktav. Ved annen gangs forsøk hendte det en sørgelig tilleggsmutasjon, nemlig en

inversjon i det genetisk-musikalske alfabet. Mens han tidligere sang perfekt

$\mathrm{F}$

E

D

C

kunne han etter inversjonen bare synge

C

$\mathrm{H}$

A
E

D

C

hvilket ble meget stereotypt.

Gjentatte bølgebad brakte ingen endring i forholdet, men sangeren har fortsatt behandlingen på egen hand (se fig. 8), idet han formener at genene sitter i hodet. Han har dessuten tatt engasjement ved «Najade», en typisk tidevannsrestaurant.

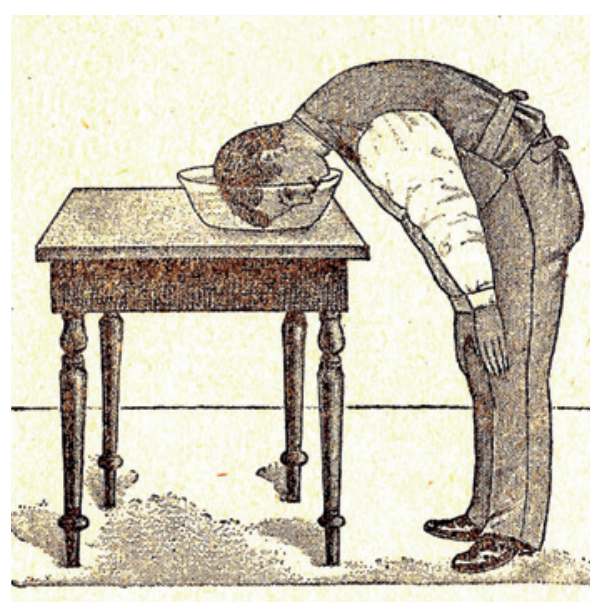

Fig. 8. 